\title{
Sediment accumulation and carbon, nitrogen, and phosphorus deposition in the large tropical reservoir Lake Kariba (Zambia/Zimbabwe)
}

\author{
Manuel J. Kunz, ${ }^{1,2}$ Flavio S. Anselmetti, ${ }^{1,2}$ Alfred Wüest, ${ }^{1,2}$ Bernhard Wehrli, ${ }^{1,2}$ \\ Adrian Vollenweider, ${ }^{1,2}$ Silvan Thüring, ${ }^{1}$ and David B. Senn ${ }^{1,2}$ \\ Received 30 August 2010; revised 28 February 2011; accepted 14 March 2011; published 12 July 2011.
}

[1] Large dams affect the aquatic continuum from land to ocean by accumulating particles and nutrients in their reservoirs. We examined sediment cores to quantify sediment, organic carbon (OC), nitrogen $(\mathrm{N})$, and phosphorous $(\mathrm{P})$ accumulation, and to examine historic changes and spatial variability in the sedimentation pattern in Lake Kariba, the largest hydropower reservoir in the Zambezi River Basin (ZRB). Sediment characteristics (concentrations of OC, N, P; $\delta^{13} \mathrm{C}$ and $\delta^{15} \mathrm{~N}$; wet bulk density) showed large variability both with sediment depth and between cores. While organic matter $(\mathrm{OM})$ in river deltas was primarily allochthonous in origin, $\mathrm{OM}$ characteristics $\left(\delta^{13} \mathrm{C}, \mathrm{C}: \mathrm{N}\right)$ in lacustrine sediments suggest that autochthonous sources account for $>45 \%$ of the OM that accumulates over large areas of the lake. At the same time, the relative contribution of allochthonous material within individual layers of lacustrine cores varied considerably with depth due to discrete flood deposits. The overall sediment accumulation rate in Lake Kariba is on the order of $4 \times 10^{6} \mathrm{t} \mathrm{yr}^{-1}$, and the estimated OC accumulation of $120 \times 10^{3} \mathrm{t} \mathrm{C} \mathrm{yr}^{-1}$ accounts for $\sim 1 \%$ of globally buried OC in reservoirs. In addition, mass balance calculations revealed that approximately $70 \%$ and $90 \%$ of incoming total $\mathrm{N}$ and $\mathrm{P}$, respectively, are eliminated from the water column by sedimentation $(\mathrm{N}, \mathrm{P})$ and denitrification (N). Since Lake Kariba attenuates flow from $\sim 50 \%$ of the ZRB, these OC, $\mathrm{N}$, and $\mathrm{P}$ removals represent a drastic reduction in nutrient loadings to downstream riparian ecosystems and to the coastal Indian Ocean.

Citation: Kunz, M. J., F. S. Anselmetti, A. Wüest, B. Wehrli, A. Vollenweider, S. Thüring, and D. B. Senn (2011), Sediment accumulation and carbon, nitrogen, and phosphorus deposition in the large tropical reservoir Lake Kariba (Zambia/Zimbabwe), J. Geophys. Res., 116, G03003, doi:10.1029/2010JG001538.

\section{Introduction}

[2] While large dams are constructed to provide socioeconomic benefits in the form of hydropower, water storage and flood control, they typically also have major adverse impacts on ecosystem services [Rosenberg et al., 2000; World Commission on Dams, 2000]. These impacts result from a range of factors, including highly altered flow regime [Richter et al., 1996], trapping of particles [Vörösmarty et al., 2003; Walling, 2006] and associated nutrients [Bosch, 2008; Bosch and Allan, 2008; Haregeweyn et al., 2008; Harrison et al., 2009; Teodoru and Wehrli, 2005] and altered water quality and nutrient dynamics [Friedl and Wüest, 2002; Matzinger et al., 2007]. Globally, dams have dramatically changed the transfer of particles from land to ocean, decreasing particle loads to the ocean by $>50 \%$ [Vörösmarty

\footnotetext{
${ }^{1}$ Surface Waters-Research and Management, Eawag: Swiss Federal Institute of Aquatic Science and Technology, Kastanienbaum, Switzerland.

${ }^{2}$ Institute of Biogeochemistry and Pollutant Dynamics, ETH Zurich, Zurich, Switzerland.
}

Copyright 2011 by the American Geophysical Union. 0148-0227/11/2010JG001538 et al., 2003]. Furthermore, reservoirs are considered to play an important role in the global carbon (C) cycle [Battin et al., 2009], by burying a large fraction of terrestrial organic $\mathrm{C}$ (OC) that would otherwise reach the oceans [Cole et al., 2007; Dean and Gorham, 1998; Downing et al., 2008; Stallard, 1998], and by emitting greenhouse gases such as $\mathrm{CO}_{2}$ and $\mathrm{CH}_{4}$ [Alin and Johnson, 2007; DelSontro et al., 2010; Tranvik et al., 2009].

[3] Less economically developed regions of the world have considerable untapped hydropower potential [Bartle, 2002; Hydropower and Dams, 2001]. This is particularly true in Africa, where only $\sim 5 \%$ of the existing hydropower potential is being utilized [Bartle, 2002; Hydropower and Dams, 2001] and where ongoing economic development drives the planning for new dams [McCartney, 2009]. Sparse biogeochemical data in such developing regions limit the ability to reliably evaluate the ecological impacts of existing and proposed dams.

[4] The Zambezi River Basin (ZRB) is a particularly relevant example. The Zambezi is the fourth largest river in Africa (area $=1,400,000 \mathrm{~km}^{2}$; average runoff $\mathrm{Q}=6,980 \mathrm{~m}^{3} \mathrm{~s}^{-1}$; [Latrubesse et al., 2005]) and is highly fragmented by large 


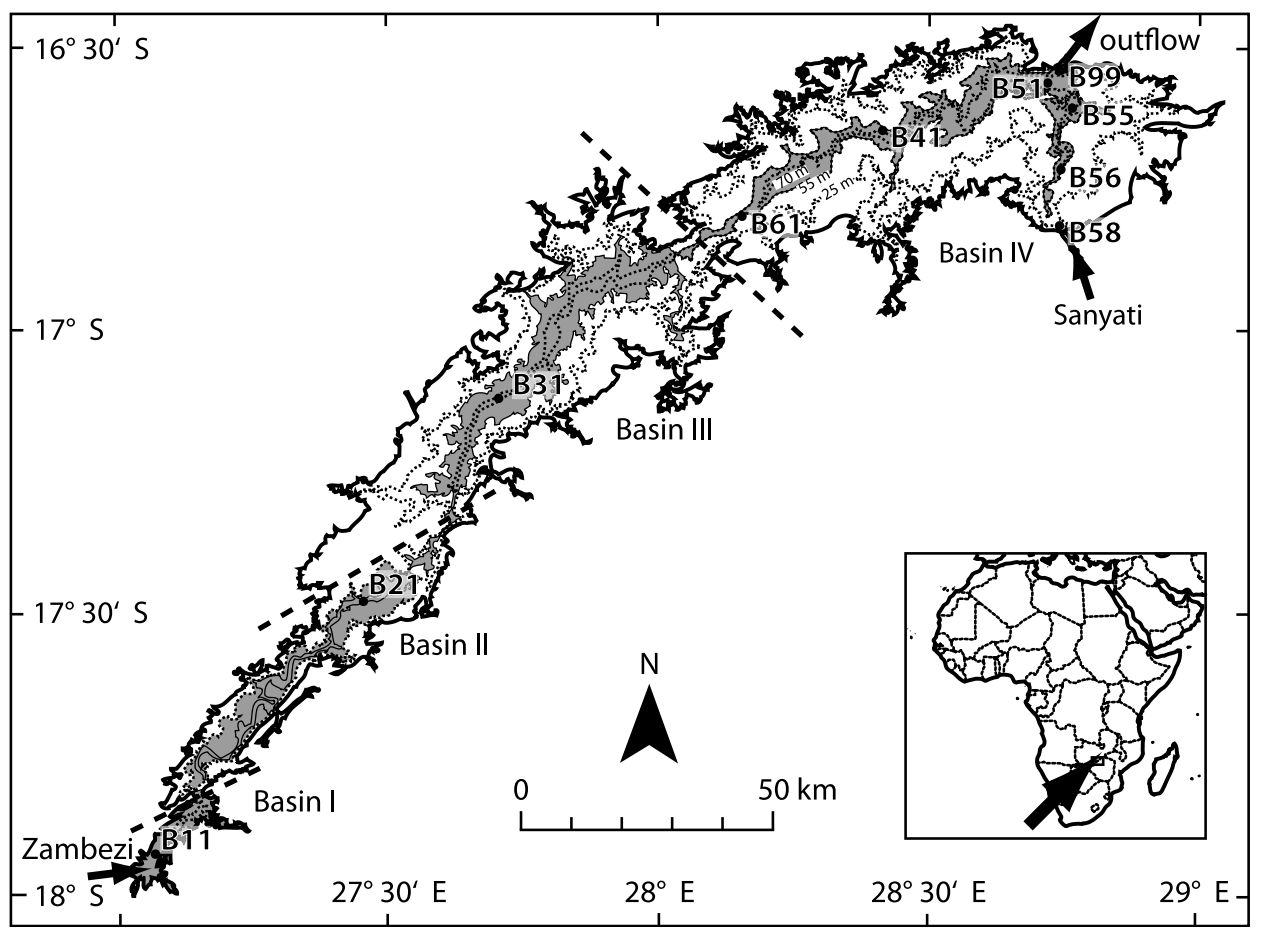

Figure 1. Bathymetric map of Lake Kariba with interbasin boundaries indicated by dashed lines (adapted from Coche [1974]). Lake Kariba is located on the border between Zambia and Zimbabwe, in the middle Zambezi (see inset). Sediment coring sites are indicated by dots; major inflows and the outflow at the dam are marked by black arrows. Sediment traps were moored at station B99 in front of the dam. The gray shaded area delineates the lacustrine sedimentation area (see text).

hydropower structures [Shela, 2000]. The hydrology of the system has been extensively studied [Beilfuss and Dos Santos, 2001; Vörösmarty and Moore, 1991] and there is evidence of massive disturbances to downstream ecosystems, particularly due to altered flooding regimes [Beilfuss and Davies, 1999], as well as river-bank and coastal erosion [Guy, 1981; Scodanibbio and Mañez, 2005]. While several studies have investigated the basic limnology during the early stages of the reservoirs [e.g., Coche, 1974] and lake productivity and fisheries potential [e.g., Marshall, 1979], there has been only limited exploration of the biogeochemical impacts of the ZRB's reservoirs on downstream systems [Attwell, 1970; Ronco et al., 2009]. Moreover, only $30 \%$ of the ZRB's hydropower capacity is currently being utilized, and several new large dams are in various stages of advanced planning [McCartney, 2009; Shela, 2000]. Thus, there is a critical need to understand the current biogeochemical impacts, as these new dams will exert further pressure on the environment.

[5] The goal of this study was to quantify the current and historic impact of Lake Kariba (Zambia/Zimbabwe), the largest reservoir in the ZRB, on the downstream transport and the cycling of particles, OC, nitrogen $(\mathrm{N})$, and phosphorus (P). Lake Kariba, one of the world's largest reservoirs by volume (volume $=157 \mathrm{~km}^{3}$, area $=5364 \mathrm{~km}^{2}$, maximal depth $=97 \mathrm{~m}$, [Coche, 1968; Magadza, 2006]), is the first of two reservoirs along the Zambezi main stem and regulates runoff from $667,000 \mathrm{~km}^{2}$ or $49 \%$ of the ZRB [Magadza, 2006]. Although negative downstream effects of Kariba Dam have been documented [Attwell, 1970; Soils
Incorporated (Pty) Ltd and Chalo Environmental and Sustainable Development Consultants, 2000], the potential causes have not been examined in details, and neither sedimentation nor removal of C, N and P in Lake Kariba have been sufficiently characterized. We examined the sediment record of Lake Kariba by analyzing physical and chemical properties of sediment cores collected at ten locations and of sediment-trap material, and used these archives to explore the following questions: (1) What is the magnitude of sediment trapping in Lake Kariba, and how do sedimentation and sediment composition vary spatially and temporally? (2) To what extent does Lake Kariba influence $\mathrm{C}$ cycling by burying and mineralizing allochthonous $\mathrm{OC}$ and fixing new (autochthonous) OC? (3) How much $\mathrm{N}$ and $\mathrm{P}$ are removed to the sediments, and how much $\mathrm{N}$ is additionally lost by denitrification?

\section{Study Area}

[6] After dam closure in 1958, Lake Kariba (Figure 1) filled over a period of 5 years. The mean total inflow is $\sim 60 \mathrm{~km}^{3} \mathrm{yr}^{-1}$, resulting in a residence time of $\sim 3$ years [Marshall, 1988]. The Zambezi accounts for $\sim 80 \%$ of inflowing water, while the Sanyati, which enters closer to the dam from the south (Figure 1), accounts for $\sim 8 \%$ [Marshall, 1988]. Coche [1974] described the lake's highly dendritic shape encompassing numerous isolated bays (shoreline length $\sim 2000 \mathrm{~km}$ ) and its morphobathymetry, featuring four distinct subbasins (basins I-IV, Figure 1). The lake is described as warm, nutrient-poor and monomictic 
[Marshall, 1988]. Annual flooding occurs between November and May during and after the rainy season [Karenge and Kolding, 1995], followed by a dry period of cooling, triggering complete deep convective mixing in July. Subsequently, thermal stratification is reestablished.

\section{Methods}

\subsection{Sample Collection and Preparation}

[7] Sediment cores from ten sites (Figure 1) were retrieved during three field campaigns (July 2007, May 2008, and February 2009) using a gravity corer (UWITEC) equipped with $6.3 \times 60 \mathrm{~cm}$ PVC tubes. The tubes were immediately sealed after sampling to minimize disturbance during transport. Cores were transported upright and, upon arrival at the laboratory, stored at $4^{\circ} \mathrm{C}$ until further processing.

[8] Wet bulk density (WBD) was measured with gamma ray attenuation on whole cores with a Geotek Multisensor core logger at a downcore resolution of $5 \mathrm{~mm}$. Cores were split vertically, and digital photographs were taken from fresh surfaces after opening. Subsequently $(\sim 1 \mathrm{~h}$ after opening), color reflectance of normal light on the split core surface was measured using a Jai CV L105 e CCD Color Line Scan Camera at a downcore resolution of 140 pixel cm $\mathrm{cm}^{-1}$.

[9] The working halves of the cores of the 2007 and 2008 campaigns were subsampled at $1 \mathrm{~cm}$ depth intervals (cores B21, B55, B56, B58; Figure 1), or from similarly colored layers (B11, B41, B51, B61, B99; Figure 1) to investigate characteristics of individual layers. Additionally, samples from pure colored (i.e., black versus bright) layers were collected from supplementary cores retrieved from stations B21, B31 and B99 during the 2009 field campaign. All samples were freeze-dried until they reached constant mass, homogenized and stored in plastic boxes. The mass of dried material from a core depth increment divided by the increment volume was calculated to give dry bulk density, which was used for calculating mass accumulation rates.

[10] To estimate gross autochthonous sedimentation rates, sediment traps (collecting area $=66 \mathrm{~cm}^{2}$ ) were moored at site B99 (Figure 1), at 2.8, 55.6 and $61.7 \mathrm{~m}$ above the bottom between July 2007 and June 2009. This station, which was located the furthest distance from major inflows, was selected to maximize the relative contribution of autochthonous material to the traps. Traps were recovered in May 2008, February 2009 and June 2009. Samples were frozen within $5 \mathrm{~h}$ after collection. Prior to analysis, the samples were freeze-dried, weighed, and homogenized.

[11] In addition to sediment sampling, water samples were collected during the three field campaigns. To estimate nutrient discharges through the outflow we collected water samples at B99 (Figure 1) throughout the water column and specifically at depths of the turbine intakes (i.e., between 7 and $44 \mathrm{~m}$ depth). Water samples were also collected at all stations depicted in Figure 1 at 5 to $10 \mathrm{~m}$ depth resolution for measuring $\mathrm{pH}$ and alkalinity by endpoint titration.

\subsection{Sample Analysis}

[12] Elemental composition $(\mathrm{C}, \mathrm{N})$ and stable-isotope ratios $\left(\delta^{13} \mathrm{C}, \delta^{15} \mathrm{~N}\right)$ were measured using a $6890 \mathrm{~N}$ Elemental Analyzer (Agilent Technologies) coupled with an Isoprime continuous flow isotope-ratio mass spectrometer (Micromass).
Stable-isotope ratios were expressed in the $\delta$ notation using the Vienna Pee Dee Belemnite and atmospheric $\mathrm{N}_{2}$ as standards. Reproducibility for replicate measurements was better than $3 \%$ and $5 \%$ for total $\mathrm{C}$ (TC) and total $\mathrm{N}(\mathrm{TN})$, respectively, and $0.1 \%$ and $1.0 \%$ for $\delta^{13} \mathrm{C}$ and $\delta^{15} \mathrm{~N}$, respectively.

[13] Based on the catchment geology, allochthonous inorganic C (IC) input to the sediments was expected to be low [Coche, 1974]. We confirmed this by analyzing both IC and OC on more than $50 \%(n=137)$ of all samples across all cores and depositional environments in two ways: by directly analyzing $\mathrm{OC}$ on samples acidified with $12 \% \mathrm{HCl}$ using the elemental analyzer [Müller and Gastner, 1971; Yamamuro, 2000], and indirectly by subtracting TIC (measured using a UIC Inc. CM $5012 \mathrm{CO}_{2}$ coulometer [Müller and Gastner, 1971]) from TC. The comparison of TC and OC revealed that $98 \pm 3 \%$ of TC was OC. A similar analysis comparing $\delta^{13} \mathrm{C}$ of acidified and untreated samples showed small $(<1.0 \%)$ and nonsystematic differences. Hence, we hereafter use measurements performed on untreated samples for $\mathrm{OC}$ concentrations and $\mathrm{OC}-\delta^{13} \mathrm{C}$.

[14] Total P (TP) concentrations of sediment and supplementary water samples were determined photometrically on a Procon flow analyzer after digesting the samples with $\mathrm{K}_{2} \mathrm{~S}_{2} \mathrm{O}_{8}$ at $120^{\circ} \mathrm{C}$ for $2 \mathrm{~h}[D E W, 2002]$. Reproducibility for replicate measurements was better than $5 \%$.

[15] To examine the fining of allochthonous particles with increasing distance from river mouths, grain size distribution was measured on wet sediment samples by laser diffraction (Malvern Mastersizer 2000). For this analysis, only samples from the transect toward Sanyati (cores B55, B56 and B58) were used.

[16] Core B55 was selected for radionuclide dating as it visually had the best preserved layering. Hence, B55 served as an example core for establishing the chronology of Lake Kariba. Gamma spectrometric measurements for ${ }^{210} \mathrm{~Pb}$ (at $46.5 \mathrm{keV}$ ) and ${ }^{137} \mathrm{Cs}$ (at $662 \mathrm{keV}$ ) were carried out on well-type GeLi-detectors. ${ }^{210} \mathrm{~Pb}$ activities showed erratic depth profiles. Therefore, only ${ }^{137} \mathrm{Cs}$ data were used for chronological interpretation.

\section{Results}

\subsection{Sediment Stratigraphy}

[17] Station B55 is located in a deep ( $\sim 80 \mathrm{~m})$ and clearly lacustrine zone of Basin IV, situated $\sim 30 \mathrm{~km}$ from the Sanyati, Kariba's second largest tributary. We expected that B55's location would allow its sediments to record both allochthonous and autochthonous inputs, and used core B55 for the initial description and characterization of sediment stratigraphy. From WBD measurements, two major sections could be distinguished (Figure 2a). Sediments in the top $\sim 15 \mathrm{~cm}$ are characterized by a low density of $\sim 1 \mathrm{~g} \mathrm{~cm}^{-3}$. Below $15 \mathrm{~cm}$, the density increases sharply over a $1 \mathrm{~cm}$ transition zone to values between 1.6 and $1.8 \mathrm{~g} \mathrm{~cm}^{-3}$. We interpret the sharp density gradient as marking the transition between predam and postdam (i.e., the reservoir filling period) deposits, an observation that is consistent with other geochemical data described below. Density variations were small in the postdam deposits, except for the section between 4.5 and $7.0 \mathrm{~cm}$ depth, containing slightly denser material (Figure 2a). 


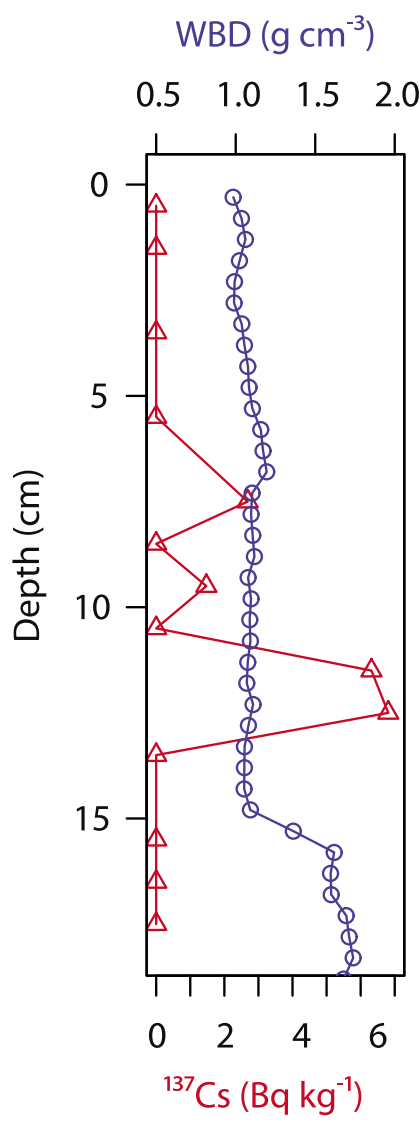

a

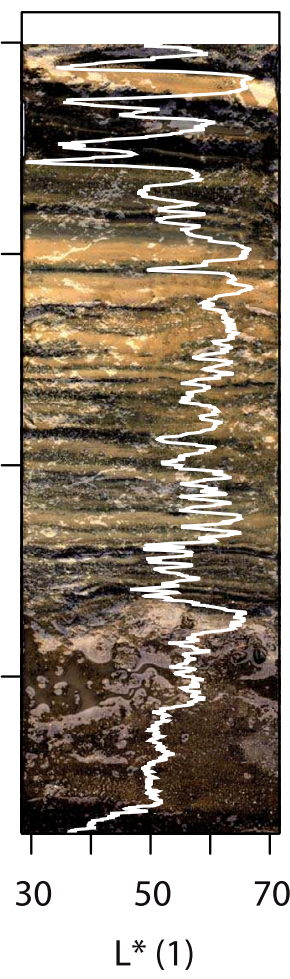

b

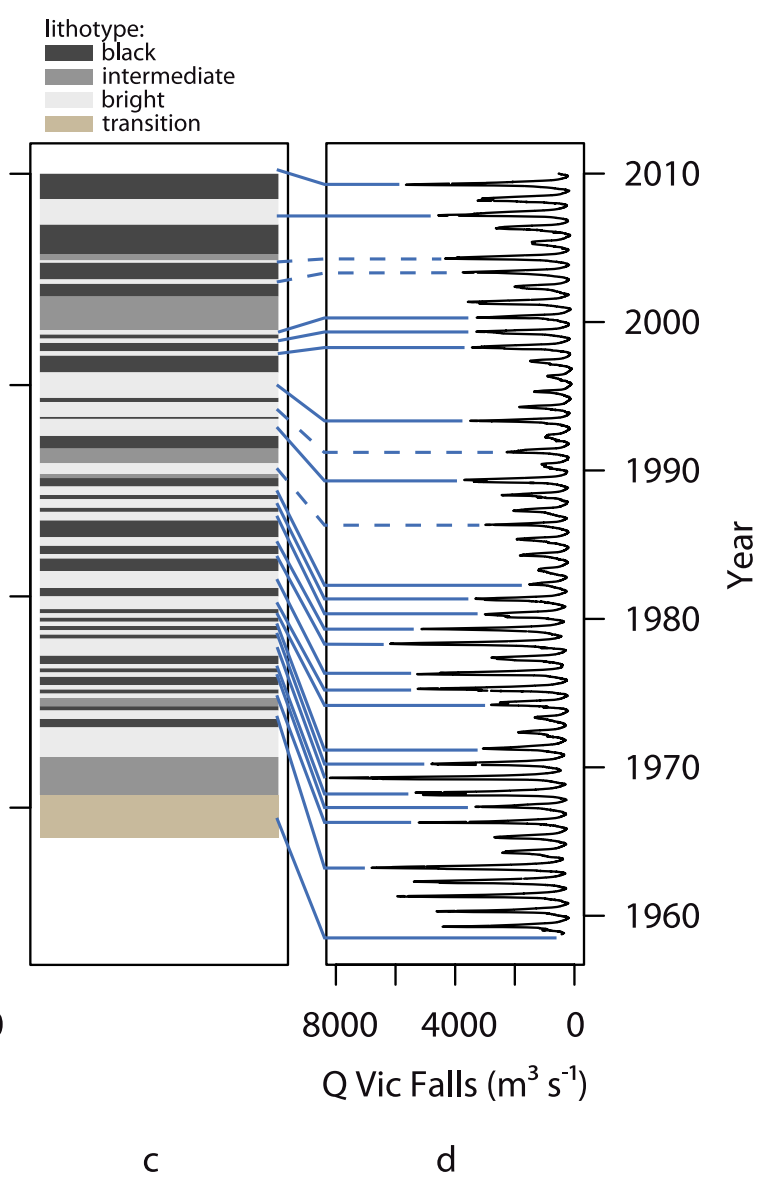

C

Figure 2. Stratigraphy and chronology of core B55 (Figure 1) illustrated by (a) depth profiles of WBD (blue) and ${ }^{137} \mathrm{Cs}$ activity (red); (b) photograph of sediment core with superimposed color reflectance ( $\mathrm{L}^{*}$, white line); (c) four lithotypes are distinguished in the postdam section indicated by different colors; and (d) Zambezi discharge at Victoria Falls. Sediment layers were dated based on the abrupt change in WBD, bomb fallout signals in ${ }^{137} \mathrm{Cs}$ activity, and their relation to discharge peaks at Victoria Falls (blue lines connecting Figures $2 \mathrm{c}$ and $2 \mathrm{~d}$ ). Lower parts of the predam sediments $(18$ to $29 \mathrm{~cm}$ ) are not shown (see Figure 3). The core photograph was optimized for brightness and contrast. Note the reflections in the photograph due to the wet, freshly cut surface, which also affected absolute $\mathrm{L}^{*}$.

[18] Within the postdam sediments, a sequence of differently colored layers (light brown, black, and intermediate gray-brown) of varying thickness could be visually distinguished in the core (Figure 2b). The color layering of the postdam sediments was confirmed by variations in color reflectance $L^{*}$ (white line in Figure $2 b$ ). Local $L^{*}$ maxima $(\sim 65)$ and local minima $(\sim 30$ to $\sim 45)$ coincide with bright and black layers, respectively. We interpreted the layering, and the varying layer thicknesses, as resulting from seasonal or interannual variations in the loadings from different sediment sources, i.e., seasonal or interannual variations in flood-induced, allochthonous sediment inputs versus internal primary production yielding autochthonous sediment inputs. The geochemical signatures of the respective layers support the notion of differing relative contributions from allochthonous and autochthonous OM sources, as described in the following section. Based on this analysis of sediment density, $\mathrm{L}^{*}$, and color or brightness, we defined four lithotypes to describe the core's stratigraphy in the postdam section (Figure 2c): (1) black colored, (2) bright colored, (3) intermediate colored, and (4) transitional density. Lith- ological variations in the predam sediments were not further explored because they are unrelated to the dam.

[19] Cores B21, B31, B61, B41, and B51 showed similar sequences of the four lithotypes in the postdam section, and the sharp increase in density to the predam section (Figure 3, top). Cores B99 and B56 also exhibited the color stratigraphy; however, they do not have sharp basal increases in density, indicating that the corer did not penetrate through the entire postdam deposits and did not reach the predam sediments at these sites. Cores B11 and B58 were different from all other cores in that they were visually homogeneous over their entire thickness with no color variation of layers and higher but relatively constant WBD (Figure 3, top).

\subsection{Chemical and Isotopic Composition}

[20] Substantial differences in the geochemical composition of the sediments from Lake Kariba were evident, both between cores and within individual vertical profiles (Figure 3, bottom and Figure 4). OC concentrations in postdam sections of the lacustrine cores (B21, B31, B61, B41, B51, B99, B55, and B56) were significantly ( $<<0.001$, 


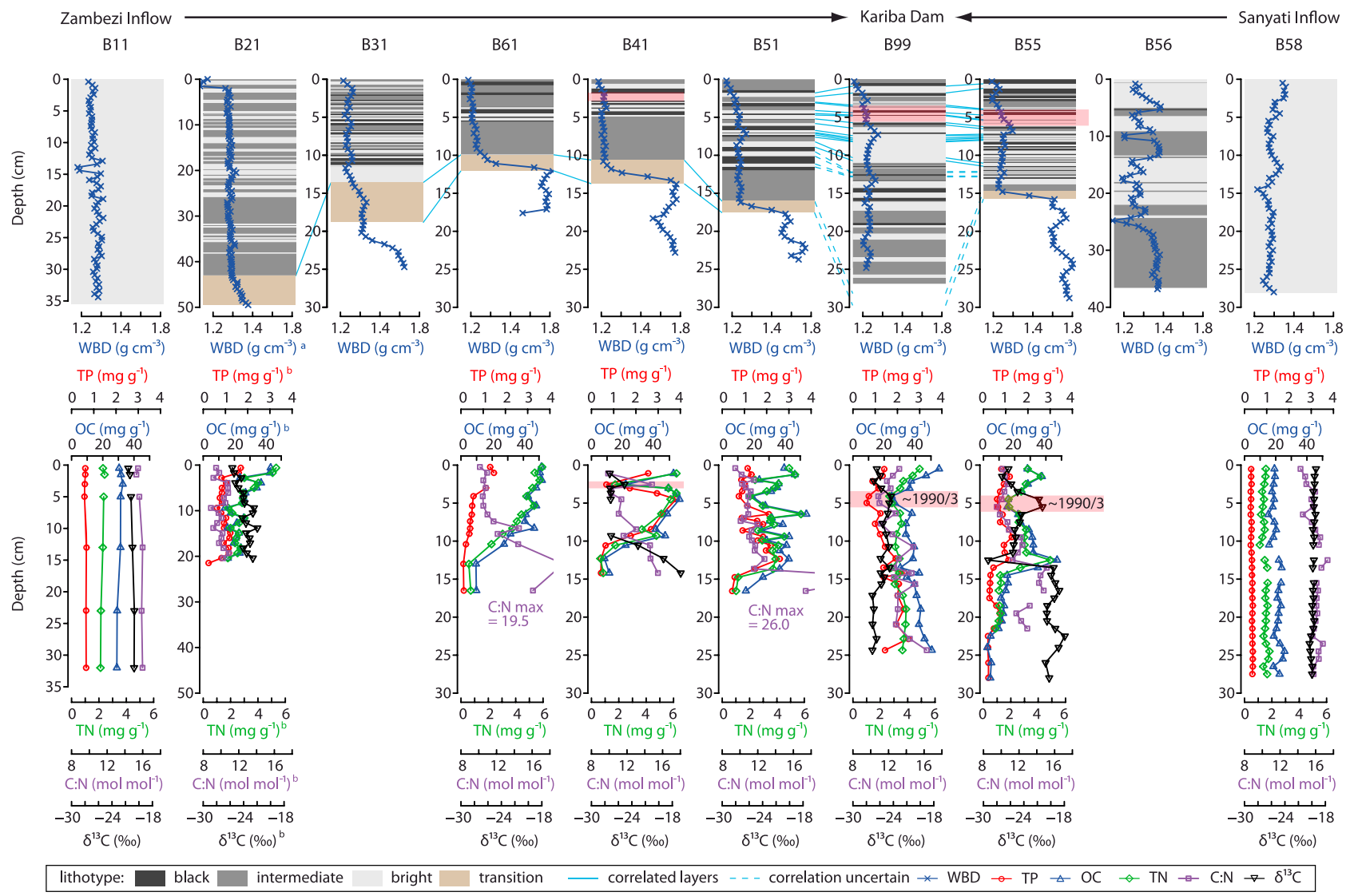

Figure 3. (top) Core stratigraphy and depth profiles of WBD, and (bottom) depth profiles of OC, TN, $\mathrm{TP}, \mathrm{C}: \mathrm{N}$ and $\delta^{13} \mathrm{C}$. Correlated layers are indicated by blue lines, and dashed lines depict uncertain correlations. Color shading indicates lithotype as shown in Figure 2. The letter "a" indicates data from core retrieved at B21 in 2009, and the letter "b" indicates data from a shorter core retrieved at B21 in 2007.

ANOVA) greater than OC concentrations in their respective predam sections, as well as in cores taken in areas close to the inflows, hereafter referred to as "riverine" cores (B11 and B58). Postdam layers also had significantly higher $\mathrm{TN}$ and TP concentrations and significantly lower $\delta^{13} \mathrm{C}$ and $\mathrm{C}: \mathrm{N}$ than predam and riverine sediments $(\mathrm{p}<0.001$, ANOVA; Figure 4). However, predam sediments and riverine cores only differed significantly in their OC levels $(\mathrm{p}<0.001)$, and not in other chemical parameters $(\mathrm{p}>0.2)$. Although mean $\delta^{15} \mathrm{~N}$ values of lacustrine postdam sediments were significantly lower than lacustrine predam sediments (Figure 4 and Figure S1, available as auxiliary material), the lacustrine postdam samples did not differ significantly $(\mathrm{p}=0.8$; Figure 4) from riverine samples, suggesting that riverine influence is not reflected in this parameter. ${ }^{1}$ The difference between riverine and lacustrine sediments was, however, evident in grain size measurements, which showed a clear fining from B58 to B55 (Figure S2, available as auxiliary material). Median grain size decreased from $13.8 \pm 2.6 \mu \mathrm{m}$ at B58 to $2.6 \pm 0.4 \mu \mathrm{m}$ in postdam deposits at B55. In comparison, predam sediments at B55 consisted of significantly coarser material (Welch Two Sample $t$ test, $\mathrm{p}<0.001$, median $=46.2 \pm 11.3 \mu \mathrm{m})$.

\footnotetext{
${ }^{1}$ Auxiliary materials are available in the HTML. doi:10.1029/ 2010JG001538.
}

[21] The elemental and isotopic composition of sedimenttrap material differed considerably from postdam sedimentcore samples. In particular, OC and TN concentrations in sediment trap material were significantly $(\mathrm{p}<0.001)$ greater than in postdam sediments, and $\delta^{13} \mathrm{C}$ and $\mathrm{C}: \mathrm{N}$ were lower (Figure 5 and Table 1). Based on the higher masses collected between 2007 and 2008, and the lower OC and TN concentrations (Table 1), it is likely that the traps collected a high portion of flood-derived matter during this period. Therefore, we used the 2008/2009 samples for subsequent calculations related to the composition and sedimentation of autochthonous material.

[22] Despite the clear layering in the postdam sediments, there are few readily apparent correspondences between the vertical profiles of the postdam sediments' chemical compositions (Figure 3, bottom) and their visual stratigraphy (Figure 3, top). We suspected that this limited correspondence resulted from the relatively coarse subsampling $(1 \mathrm{~cm})$ compared to the thickness of many of the dark layers, which was unavoidable in many cases because of the extremely thin (millimeters) layering. Subsequent measurements of lithologically pure layers (black versus bright) from the 2009 cores showed that geochemical differences between the black and bright lithotypes were indeed apparent (Figure 6). Pure black layers had significantly higher $(p<0.01)$ OC and TN concentrations, and signifi- 
OC $\left(\mathrm{mg} \mathrm{g}^{-1}\right)$

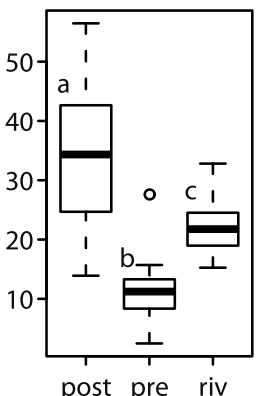

$\mathrm{C}: \mathrm{N}\left(\mathrm{mol} \mathrm{mol}^{-1}\right)$

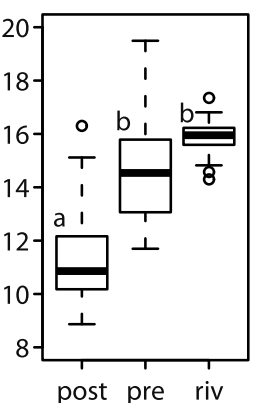

$\mathrm{TN}\left(\mathrm{mg} \mathrm{g}^{-1}\right)$

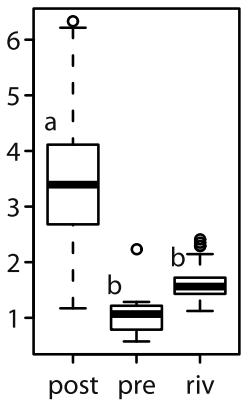

$\delta^{13} \mathrm{C}(\%)$

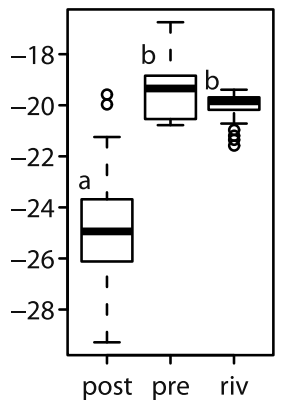

TP $\left(\mathrm{mg} \mathrm{g}^{-1}\right)$

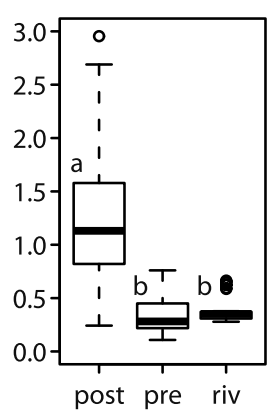

$\delta^{15} \mathrm{~N}(\%)$

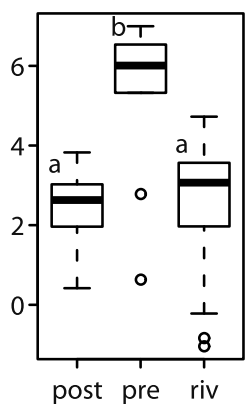

Figure 4. Box plots of $\mathrm{OC}, \mathrm{TN}, \mathrm{TP}, \mathrm{C}: \mathrm{N}, \delta^{13} \mathrm{C}$, and $\delta^{15} \mathrm{~N}$ of postdam ("post") and predam ("pre") core sections, and of riverine ("riv") cores. Between these three sediment types, there are significant differences, indicated by letters "a," "b," and "c" ( $<0.001$, ANOVA). Postdam sediments differ from predam and riverine sediments, except for $\delta^{15} \mathrm{~N}$. In turn, predam and riverine sediments do not differ significantly $(\mathrm{p}>0.2)$, except for OC.

cantly lower $(\mathrm{p}<0.001) \delta^{13} \mathrm{C}$ values than bright layers; mean $\mathrm{C}: \mathrm{N}$ values, however, did not differ significantly $(\mathrm{p}=$ $0.2,11.3 \pm 1.3$ and $10.4 \pm 1.3$, respectively). Further, when combining measurements from all cores and sediment traps in plots of $\delta^{13} \mathrm{C}$ against $\mathrm{OC}$ and $\mathrm{C}: \mathrm{N}$, distinct groupings and systematic variations become evident (Figure 5). Predam sediments and samples from riverine cores grouped together and displayed the highest values for $\delta^{13} \mathrm{C}$ and $\mathrm{C}: \mathrm{N}$ and the lowest OC concentrations. Sediment-trap material plotted at the opposite end of Figure 5 having the lowest values for $\delta^{13} \mathrm{C}$ and $\mathrm{C}: \mathrm{N}$ and the highest $\mathrm{OC}$ concentrations. Postdam sediments from lacustrine cores were distributed between these two end-member groups (Figure 5). Within Figure 5, several postdam sediment layers plotted separately from other layers in the same core (e.g., core B41 2.2 to $2.9 \mathrm{~cm}$; B99 4.4 to $4.7 \mathrm{~cm}$; B55 4.7 to $5.3 \mathrm{~cm}$ ), shifted toward riverine or predam sediments. These layers also had locally distinct TN and TP concentrations, higher WBD (Figure 3), and higher mean grain size (Figure S2, available as auxiliary material).

\subsection{Age Model and Sediment Accumulation Rates}

[23] The layered sediment structure and three key time horizons were used to develop an age model for the postdam section of core B55. A first time horizon was defined by the core surface, dating to core retrieval in 2008. Second, the bottom of the low to high density transition zone $(15.7 \mathrm{~cm})$, which coincided with the onset of the lacustrine depositional regime, was set to the year of dam closure, 1958. For the third time horizon, the ${ }^{137} \mathrm{Cs}$ peak at $12.5 \mathrm{~cm}$ depth (Figure 2a) was matched with the historic maximum of atmospheric fallout from nuclear weapons testing in 1963. It should be noted that considerable uncertainty may be associated with the ${ }^{137} \mathrm{Cs}$-derived time horizon, as the erratic ${ }^{210} \mathrm{~Pb}$ profiles point to irregular supply of allochthonous radiogenic isotopes.

[24] Building on the interpretation that dark autochthonous sediment was intercalated by brighter flood layers deposited during intense annual runoff events in the Zambezi, long-term discharge records of the Zambezi at Victoria Falls ( $150 \mathrm{~km}$ upstream of Lake Kariba; Figure 2d [Zambezi River Authority, 2010]) were used to approximately date some individual layers by attributing bright and dark layer pairs
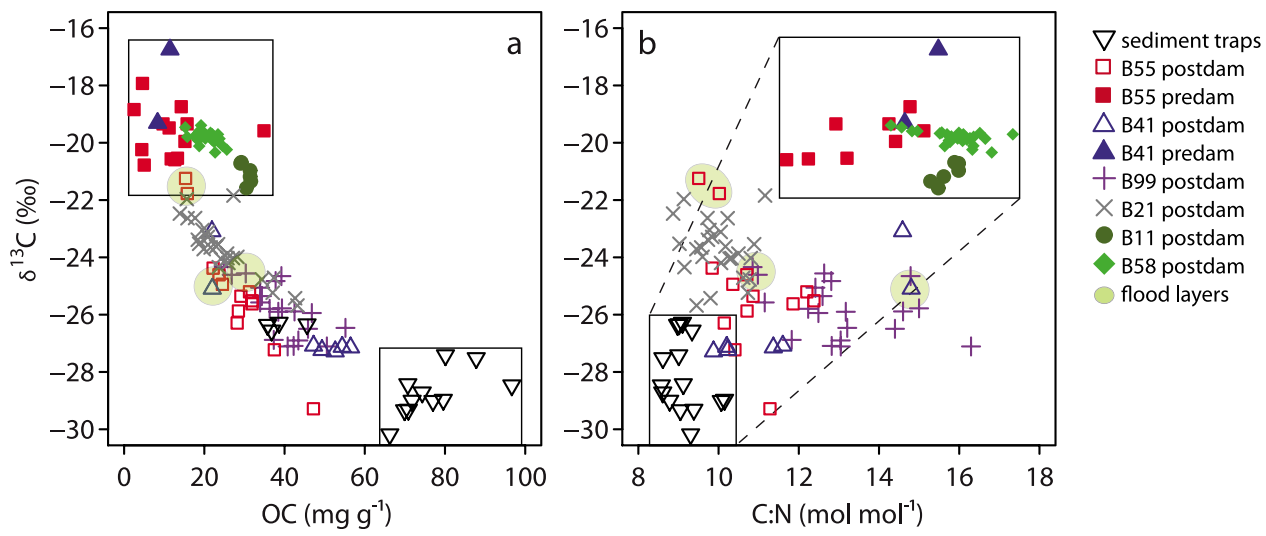

Figure 5. Scatterplots of (a) $\delta^{13} \mathrm{C}$ against $\mathrm{OC}$ and (b) $\delta^{13} \mathrm{C}$ against $\mathrm{C}: \mathrm{N}$ ratio. Solid symbols denote samples from predam deposits or from riverine cores. Open symbols denote core and sediment trap samples from postdam period. For the latter, high OC, low C:N ratios and low $\delta^{13} \mathrm{C}$ values indicate low contents of allochthonous matter. Points highlighted by shaded ellipses have a maximal allochthonous signature within the samples of the respective core, and therefore are most likely flood deposits. The black boxes encompass the two hypothetical end-members of sediment sources (i.e., sediment trap samples for autochthonous organic matter (OM), predam sediments and riverine cores for allochthonous $\mathrm{OM}$ ). 
Table 1. Summary of Sediment Trap Data

\begin{tabular}{|c|c|c|c|c|c|c|}
\hline Period & $\begin{array}{c}\text { Mass } \\
(\mathrm{mg} \pm 1 \sigma)\end{array}$ & $\begin{array}{l}\text { Sedimentation Rate } \\
\left(\mathrm{g} \mathrm{cm}^{-2} \mathrm{yr}^{-1} \pm 1 \sigma\right)\end{array}$ & $\left(\mathrm{mg} \mathrm{g}^{-1} \pm 1 \sigma\right)$ & $\left(\mathrm{mg} \mathrm{g}^{-1} \pm 1 \sigma\right)$ & $\begin{array}{l}\delta^{13} \mathrm{C} \\
(\% 0)\end{array}$ & 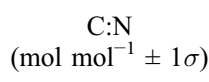 \\
\hline Jul 2007 to May 2008 & $17 \pm 7$ & $0.31 \pm 0.12$ & $39.7 \pm 5.2$ & $5.1 \pm 0.7$ & $-26.4 \pm 0.0$ & $9.1 \pm 0.1$ \\
\hline May 2008 to Jun 2009 & $6 \pm 2$ & $0.08 \pm 0.03$ & $75.5 \pm 7.8$ & $9.5 \pm 1.3$ & $-28.8 \pm 0.8$ & $9.3 \pm 0.5$ \\
\hline
\end{tabular}

to hydrological years (blue lines in Figures $2 \mathrm{c}$ and $2 \mathrm{~d}$ ). The large variation of discharge (Figure $2 \mathrm{~d}$ ) reflects interannual differences of the flood amplitude during the wet season. Over the first 22 years after dam construction (1958 to 1980), which was an above-average wet period, bright and black layer pairs could be identified for almost every year. Discharge records show that after 1980 the upper Zambezi experienced a period when drier conditions prevailed. Layering also became less pronounced after 1980, and relatively thick intermediate-colored bands are present. We interpret the gap in the sequence of flood-derived layers as having resulted from the absence of major floods, and lower particle loads to Lake Kariba. The prolonged absence of clear layers made layer identification and dating after 1980 more difficult.

[25] Sediment accumulation rates for dated layers in core B55 were estimated based on this age model. The mean mass accumulation rate recorded at B55 over the 50 years was $0.07 \mathrm{~g} \mathrm{~cm}^{-2} \mathrm{yr}^{-1}$. However, interannual variability in sediment accumulation rates, inferred from dated layers, was considerable. The highest sediment accumulation rates occurred shortly after dam closure (1958 to 1961) and during major floods (hydrological years 1962/1963, 1975/1976, 1977/1978, 2006/2007, maximum $=0.21 \mathrm{~g} \mathrm{~cm}^{-2} \mathrm{yr}^{-1}$ ). Minimum sedimentation rates appear to have been as low as $0.01 \mathrm{~g} \mathrm{~cm}^{-2} \mathrm{yr}^{-1}$ (years 1972/1973, 1981/1982, 1995/1996).

[26] Based on core photographs, there was strong correspondence between the layering patterns in core B55 and the patterns in cores from other nearby stations, in particular B51 and B99 (blue lines, Figure 3, top). Intercore similarities could also be discerned over longer transects (B21 to B99, B56 to B99). Layering was not equally preserved in cores closer to the Zambezi inflow, where density currents have more energy. Consequently, flood layers may have amalgamated, or erosional features may have occurred, ultimately causing incomplete successions of flood layers. Nonetheless, considering the large distances between stations, clear correspondence between some layers across multiple stations suggests that some major depositional events are felt at the entire lake scale. At the same time, the substantial differences in chemistry and stratigraphy between riverine sediments and postdam lacustrine sediments and between some postdam lacustrine cores clearly show that sedimentation in Lake Kariba is spatially heterogeneous and flood-dominated.

\section{Discussion}

\subsection{OM Provenance: Allochthonous Versus Autochthonous Sources}

[27] The chemical composition of OM can be used to differentiate between allochthonous and autochthonous sources to sediments [Meyers and Teranes, 2002]. OM derived from vascular plant material can in general be dis- tinguished from algal biomass by a higher C:N ( $>20$ versus 8 to 10 [Meyers and Teranes, 2002]). In addition, OM from $\mathrm{C} 4$ plants and OM from phytoplankton differ considerably in their $\delta^{13} \mathrm{C}$ ranges $(-10$ to $-15 \%$, and -20 to $-30 \%$, respectively [Meyers and Lallier-Verges, 1999; Meyers and Teranes, 2002]). In combination, these two factors cause higher $\mathrm{C}: \mathrm{N}$ and isotopically heavier $\mathrm{OC}$ in sediment as the proportion of OM from allochthonous sources increases. In turn, relatively lower $\mathrm{C}: \mathrm{N}$ and lower $\delta^{13} \mathrm{C}$ values indicate a higher proportion of algal $\mathrm{OM}$ in the sediments. Early diagenesis of OM in sediments can also cause shifts in $\mathrm{C}: \mathrm{N}$ and $\delta^{13} \mathrm{C}$ of bulk OM; however, changes in $\mathrm{C}: \mathrm{N}$ and $\delta^{13} \mathrm{C}$ due to $\mathrm{OM}$ transformations tend to be relatively small compared to the large differences between end-member compositions [Lamb et al., 2006].

[28] The separation of postdam sediment layers along the continuums in Figure 5 is consistent with the mixing of sediment material from autochthonous and allochthonous sources. The high $\mathrm{C}: \mathrm{N}$ and $\delta^{13} \mathrm{C}$ values and relatively low OC concentrations in the predam sediments of lacustrine cores, and over the entire depth of the riverine cores, are consistent with primarily allochthonous OM (Figure 5). As expected, the composition of sediment trap material (low $\mathrm{C}$ : $\mathrm{N}$ and $\delta{ }^{13} \mathrm{C}$ values) is consistent with it containing a high proportion of algal material, and thus autochthonous OM. Although the measured $\mathrm{C}: \mathrm{N}$ and $\delta^{13} \mathrm{C}$ are typical for algal biomass, Redfield-type algal $\mathrm{OM}$ has an $\mathrm{OC}$ content of $\sim 400 \mathrm{mg} \mathrm{g}^{-1}$. The measured OC concentration range of 65 to $100 \mathrm{mg} \mathrm{g}^{-1}$ in sediment-trap material may point to dilution by some OC-poor allochthonous particles, or by silica-rich and thus relatively carbon-poor autochthonous material (e.g., diatoms). Given the distance of station B99 from the major inflows and the fairly distinct signature of
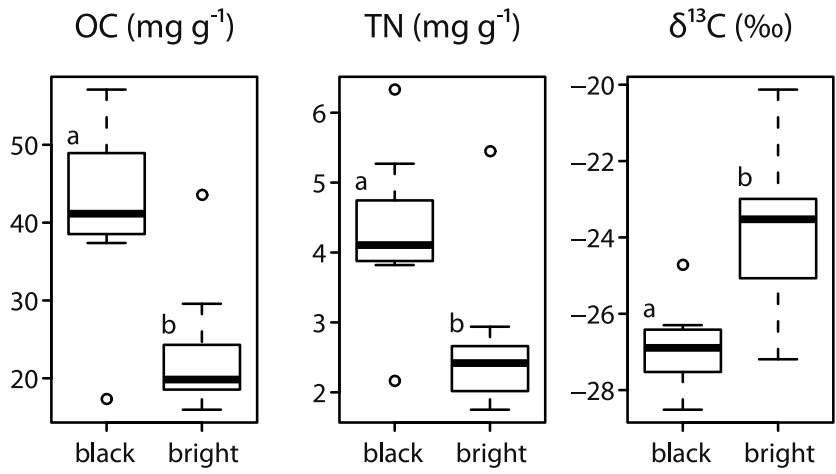

Figure 6. Box plot of $\mathrm{OC}, \mathrm{TN}$, and $\delta^{13} \mathrm{C}$ in pure lithotypic samples from the postdam sections of cores B21, B31, and B99 retrieved in February 2009 (black layers, $n=7$; bright layers, $\mathrm{n}=11$ ). Bright layers contain substantially less OC and $\mathrm{TN}$, and are isotopically heavier than black layers indicating the relatively large contribution of allochthonous OM in the flood-derived bright layers. 
Table 2. Summary of Sediment Accumulation Rates Based on the Assumption of a Uniform Sediment Distribution

\begin{tabular}{lc}
\hline \multicolumn{1}{c}{ Approach } & $\begin{array}{c}\text { Sediment Accumulation } \\
\text { Rate }\left(10^{6}{\left.\mathrm{t} \mathrm{yr}^{-1}\right)}^{-1}\right.\end{array}$ \\
\hline $\begin{array}{l}\text { Mean sediment accumulation rate, area below Mud Deposition } \\
\text { Boundary Depth [Rowan et al., 1992] }\end{array}$ & 4.1 \\
Mean sediment accumulation rate, area below epilimnion & 3.1 \\
Linearly increasing sediment accumulation rate to the base & 7.5 \\
of the epilimnion; constant rate below, whole lake surface & \\
area $\left(5364 \mathrm{~km}^{2}\right.$ ) & 6.5 \\
Sediment load estimated from TSS data for Sanyati mouth & \\
$\quad$ (Zambezi River Authority, unpublished data, 2010), & \\
scaled up to match total inflows, removal rate $100 \%$ & \\
\hline
\end{tabular}

trapped material (Figure 5), for subsequent calculations we considered the sediment trap material to be reasonably representative of autochthonous OM composition in terms of $\mathrm{C}: \mathrm{N}$ and $\delta^{13} \mathrm{C}$.

[29] We applied a simple mixing model [Waterson and Canuel, 2008] to estimate the relative contributions of allochthonous and autochthonous OM in the lacustrine postdam sediments of Lake Kariba. In this model, mean $\mathrm{C}: \mathrm{N}$ and $\delta^{13} \mathrm{C}$ values of predam and riverine samples were used to represent the allochthonous end-member composition $(16 \pm 1,-19.9 \pm 0.8 \%$, respectively). Sediment trap samples (2007/2008 period excluded, see above) were used to represent the autochthonous end-member composition (means: $9.1 \pm 0.6$ and $-28.8 \pm 0.8 \%$, respectively). Solving the mixing equations [Fry, 2006]:

$$
\delta^{13} C_{\text {postdam }}=\left(1-f_{\text {auto }}\right) \cdot \delta^{13} C_{\text {allo }}+f_{\text {auto }} \cdot \delta^{13} C_{\text {auto }}
$$

for

$$
f_{\text {auto }}=\frac{\delta^{13} C_{\text {postdam }}-\delta^{13} C_{\text {allo }}}{\delta^{13} C_{\text {auto }}-\delta^{13} C_{\text {allo }}}
$$

yields $f_{\text {auto }}=59 \pm 30 \%$ for the mean postdam sediments of the lacustrine cores $\left(\delta^{13} C_{\text {postdam }}=-25.0 \pm 1.8 \%\right.$ ). Calculating $f_{\text {auto }}$ using $\mathrm{C}: \mathrm{N}$ instead of $\delta^{13} \mathrm{C}$ results in $f_{\text {auto }}=58 \pm$ $21 \%$ (mean $C: N_{\text {postdam }}=11.8 \pm 1.9$ ). Hence, in the lacustrine cores, on average $\sim 60 \%$ of the $\mathrm{OM}$ in postdam sediments was of autochthonous origin, and $\sim 40 \%$ of allochthonous origin. As sediment-trap material contained some allochthonous contribution, and therefore had a lower $\mathrm{C}: \mathrm{N}$ ratio than pure algal OM, we also calculated $f_{\text {auto }}$ using a Redfield C:N ratio of 106:16 for $C: N_{\text {auto }}$. In this lower-end scenario for lacustrine cores, $f_{\text {auto }}$ decreased to $45 \%$.

[30] The approach used here, employing $\mathrm{OC}-\delta^{13} \mathrm{C}$ and $\mathrm{C}: \mathrm{N}$, may serve as a fairly simple method for quantifying autochthonous OC contributions in other lakes and reservoirs. In general, data on the relative contributions of allochthonous and autochthonous OC to lake sediments are sparse [Alin and Johnson, 2007] but important for estimating the anthropogenic effects of river damming on the global $\mathrm{C}$ cycle [Downing et al., 2008]. The $f_{\text {auto }}$ value of $>45 \%$ was estimated for the lacustrine sedimentation zone in Lake Kariba. If deltaic sedimentation were included to estimate a whole-lake weighted average $f_{\text {auto }}$, the value would be lower, moving in the direction of the global mean of $f_{\text {auto }}<$ $12 \%$ for allochthonous and autochthonous OC fluxes to res- ervoir sediments [Stallard, 1998]. Additionally, the higher $f_{\text {auto }}$ we obtained for Lake Kariba may be due to low allochthonous OC contributions, which may be expected due to erosion of OC-depleted Kalahari Sands [Wang et al., 2007], the dominant soil type in the Kariba catchment [Coche, 1974]. This assessment is consistent with the observations by de Junet et al. [2009], who also described relatively high autochthonous contributions to the sediments of a tropical reservoir in South America.

\subsection{Sediment Accumulation in Lake Kariba}

[31] Given the event-driven and spatially heterogeneous depositional environment in Lake Kariba, we employed multiple approaches to quantify sediment accumulation. For a first estimate of reservoir-wide sediment accumulation, we used mean sediment-core data (dry bulk density and postdam sediment thickness) and particle concentrations in the tributaries (Zambezi River Authority, unpublished data, 2010), and assumed uniform sediment distribution. This approach yielded sediment accumulation rates in the range of $\sim 3$ to $\sim 8 \times 10^{6} \mathrm{t} \mathrm{yr}^{-1}$ (Table 2).

[32] These estimates, however, do not consider the complex depositional processes in reservoirs [Shotbolt et al., 2005]. To obtain a more physically based and nuanced estimate, we developed a refined sedimentation model that takes into account the morphology of Lake Kariba, and considers two main sedimentation zones (Figure 1; for a detailed description, see auxiliary material): (1) the thalweg area (up to $10 \mathrm{~km}$ wide) following the original river channels, in which density currents deposit allochthonous sediment as distinct flood layers in addition to autochthonous sediments; (2) the littoral zones, unaffected by density currents and therefore only collecting autochthonous sediments. Following this approach, the thickness of flood layers accounted for $23,42,30$ and $30 \%$ of postdam section in basins IV, III, II and I, respectively. Near the Zambezi and Sanyati inflows, the transition between predam and postdam sections were not captured in the sediment cores (Figure 3). Hence, using the lengths of B11 and B58 cores underestimates the true sedimentation rates there. The resulting estimated total sediment accumulation rate in the littoral and lacustrine zones summed to $3.7 \times 10^{6} \mathrm{t} \mathrm{yr}^{-1}$ (Table 3), which is comparable to the range estimated above assuming uniform settling across the lake $\left(\sim 3\right.$ to $\left.\sim 8 \times 10^{6} \mathrm{t} \mathrm{yr}^{-1}\right)$, but may underestimate the accumulation in river deltas.

[33] Both estimates of total sediment accumulation are consistent with an earlier study [Bolton, 1984] that estimated 
Table 3. Summary of Sediment Accumulation Rates Based on the Lacustrine-Littoral Sediment Model

\begin{tabular}{|c|c|c|c|c|}
\hline & $\begin{array}{c}\text { Sedimentation } \\
\text { Rate } \\
\left(\mathrm{g} \mathrm{cm}^{-2} \mathrm{yr}^{-1}\right)\end{array}$ & $\begin{array}{c}\text { Dry Bulk } \\
\text { Sediment } \\
\text { Density }\left(\mathrm{g} \mathrm{cm}^{-3}\right)\end{array}$ & $\begin{array}{l}\text { Area } \\
\left(\mathrm{km}^{2}\right)\end{array}$ & $\begin{array}{c}\text { Sediment } \\
\text { Accumulation } \\
\text { Rate }\left(10^{6} \mathrm{t} \mathrm{yr}^{-1}\right)\end{array}$ \\
\hline \multicolumn{5}{|c|}{ Basin I } \\
\hline Lacustrine & 0.91 & 1.8 & 34 & 0.3 \\
\hline Littoral & 0.78 & 1.1 & 66 & 0.5 \\
\hline \multicolumn{5}{|c|}{ Basin II } \\
\hline Lacustrine & 0.18 & 0.2 & 339 & 0.6 \\
\hline Littoral & 0.13 & 0.2 & 346 & 0.4 \\
\hline \multicolumn{5}{|c|}{ Basin III } \\
\hline Lacustrine & 0.03 & 0.1 & 492 & 0.2 \\
\hline Littoral & 0.02 & 0.1 & 1555 & 0.3 \\
\hline \multicolumn{5}{|c|}{ Basin IV } \\
\hline Lacustrine & 0.06 & 0.2 & 500 & 0.3 \\
\hline Littoral & 0.05 & 0.2 & 2049 & 1.0 \\
\hline Total & 0.07 & & 5381 & 3.7 \\
\hline
\end{tabular}

a sediment accumulation rate of $7 \times 10^{6} \mathrm{t}^{-1}$ in Lake Kariba, based on erosion rates in Zimbabwean catchments, and assuming that most of the sediments produced upstream of Victoria Falls are trapped in large upstream wetlands (i.e., Barotse Plains and Chobe Swamps). Milliman and Meade [1983] estimated a sediment yield of $35 \mathrm{t} \mathrm{km}^{-2} \mathrm{yr}^{-1}$ for the entire ZRB. Applying this yield to the Kariba catchment downstream of Victoria Falls (area $=1.7 \times 10^{5} \mathrm{~km}^{2}$ [Bolton, 1984]) results in a comparable sediment load of $6 \times 10^{6} \mathrm{t} \mathrm{yr}^{-1}$ to Lake Kariba, again of comparable magnitude to the above mentioned estimate based on our sediment cores. Bolton [1984] asserted that a safe estimate for an upper bound erosional sediment yield may be an order of magnitude higher than the measured values, and arrived at a sediment accumulation range of 7 to $70 \times 10^{6} \mathrm{t} \mathrm{yr}^{-1}$. Applying a similar factor to our sediment accumulation rate, we

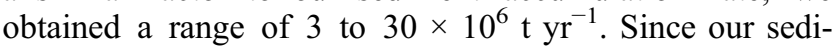
mentation model is better constrained in the lacustrine zone, any difference between the best estimate $\left(3.7 \times 10^{6} \mathrm{t} \mathrm{yr}^{-1}\right)$

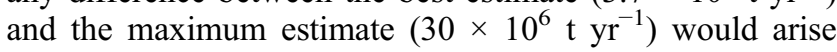
primarily through material accumulating in the deltas. Assigning this additional sedimentation entirely to the Zambezi and Sanyati deltas in Lake Kariba, and estimating the delta areas to be on the order of 200 and $50 \mathrm{~km}^{2}$, respectively, results in a sedimentation rate of $\sim 10 \mathrm{~cm} \mathrm{yr}^{-1}$ in these deltas. This value is not unreasonable; however, based on the available data, sediment accumulation rate estimates in the deltas cannot be further constrained.

\subsection{Organic Carbon Cycling and Sedimentation}

[34] Using sediment accumulation rates and OC concentrations, the rate of net $\mathrm{OC}$ accumulation in the sediments was estimated to be $120 \times 10^{3} \mathrm{t} \mathrm{yr}^{-1}$ (range $=100$ to

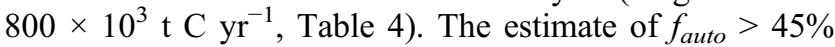
across the lacustrine areas indicates that Lake Kariba, in addition to trapping allochthonous $\mathrm{OC}$, has altered $\mathrm{OC}$ cycling in the ZRB by fostering autochthonous primary production, and removing some of this $\mathrm{OC}$ to the sediments. The estimated Kariba net $\mathrm{OC}$ accumulation rate is on the order of $1 \%$ of the global OC burial in reservoirs given by Dean and Gorham [1998]. This proportion is somewhat less than expected, as Lake Kariba covers $\sim 2 \%$ of the total global surface area of reservoirs [Downing et al., 2006]. The net $\mathrm{OC}$ accumulation rate translates to a flux of 23 (range $=$ 19 to 150$) \mathrm{g} \mathrm{C} \mathrm{m}^{-2} \mathrm{yr}^{-1}$. Comparing this estimate to mean $\mathrm{C}$ burial in reservoirs worldwide $\left(400 \mathrm{~g} \mathrm{C} \mathrm{m}^{-2} \mathrm{yr}^{-1}\right.$ [Dean and Gorham, 1998]), and in eutrophic reservoirs in Iowa, USA (148 to $17,000 \mathrm{~g} \mathrm{C} \mathrm{m}^{-2} \mathrm{yr}^{-1}$ [Downing et al., 2008]), Lake Kariba appears to accumulate $\mathrm{OC}$ at a low rate, even when maximum estimates are considered. The relatively low OC accumulation is not necessarily surprising since Kariba is oligotrophic and drains a catchment dominated by soils with low OC contents and high OM mineralization rates [Coche, 1974; Wang et al., 2007]. Assuming a low OC concentration of $\sim 0.5 \%$ [Wang et al., 2007] in allochthonous sediment, and an allochthonous sediment input of $3.7 \times 10^{6} \mathrm{t} \mathrm{yr}^{-1}$ (range $=3$ to $30 \times 10^{6} \mathrm{t} \mathrm{yr}^{-1}$, see above), the allochthonous OC input would amount to $19 \times 10^{3} \mathrm{t} \mathrm{C} \mathrm{yr}^{-1}$ (15 to $150 \times$ $\left.10^{3} \mathrm{t} \mathrm{C} \mathrm{yr}^{-1}\right)$. This value represents gross allochthonous OC input prior to any mineralization, and is thus an overestimate in that respect. Nevertheless, it is considerably lower than our estimated total OC accumulation of $120 \times 10^{3} \mathrm{t} \mathrm{yr}^{-1}$ (range $=100$ to $800 \times 10^{3} \mathrm{t} \mathrm{C} \mathrm{yr}^{-1}$ ), and further highlights the relative importance of autochthonous $\mathrm{OC}$ contributions to the sediment.

[35] The net OC accumulation in the sediments comprises the fraction of gross OC settling in the basin that is not mineralized within the water column or after deposition (Figure 7). The mean gross OC accumulation rate, estimated from the sediment traps, was $61 \pm 10 \mathrm{~g} \mathrm{C} \mathrm{m}^{-2} \mathrm{yr}^{-1}$. We compared this estimate with the mean net $\mathrm{OC}$ accumulation rate of the lacustrine zone of Basin IV $\left(=24 \pm 9 \mathrm{~g} \mathrm{C} \mathrm{m}^{-2} \mathrm{yr}^{-1}\right)$, which was calculated based on the $\mathrm{OC}$ accumulation rates for cores B41, B51, B55, B61, and B99 (Figure 1). Based on these estimates, the burial efficiency $(B E)$ of $\mathrm{OC}$, defined as

Table 4. Summary of Sediment, OC, TN, and TP Accumulation Rates ${ }^{\mathrm{a}}$

\begin{tabular}{lcccc}
\hline & \multicolumn{4}{c}{ Accumulation Rate } \\
\cline { 2 - 5 } & $\begin{array}{c}\text { Sediment } \\
\left(10^{6} \mathrm{y}^{-1}\right)\end{array}$ & $\begin{array}{c}\mathrm{OC} \\
\left(10^{3} \mathrm{t} \mathrm{C} \mathrm{yr}^{-1}\right)\end{array}$ & $\begin{array}{c}\mathrm{TN}\left(T N_{\text {sed }}\right) \\
\left(10^{3} \mathrm{t} \mathrm{N} \mathrm{yr}^{-1}\right)\end{array}$ & $\begin{array}{c}\mathrm{TP}\left(T P_{\text {sed }}\right) \\
\left(10^{3} \mathrm{t} \mathrm{yr}^{-1}\right)\end{array}$ \\
\hline $\begin{array}{l}\text { Lacustrine and littoral } \\
\text { zones in basins I-IV }\end{array}$ & 3.7 & 120 & 12 & 4.1 \\
$\begin{array}{l}\text { Range } \\
\text { Minimum }\end{array}$ & & & & \\
Maximum & 3.0 & 100 & 11 & 3.8 \\
\hline
\end{tabular}

${ }^{\mathrm{a}}$ Based on our estimated sediment accumulation rates for lacustrine and littoral zones. Minimum and maximum values are estimated based on a sediment accumulation range of 3 to $30 \times 10^{6} \mathrm{t} \mathrm{yr}^{-1}$ (see text). Multiplying sediment accumulation rates with mean concentrations of $\mathrm{OC}, \mathrm{TN}$, and $\mathrm{TP}$ resulted in respective accumulation rates. 


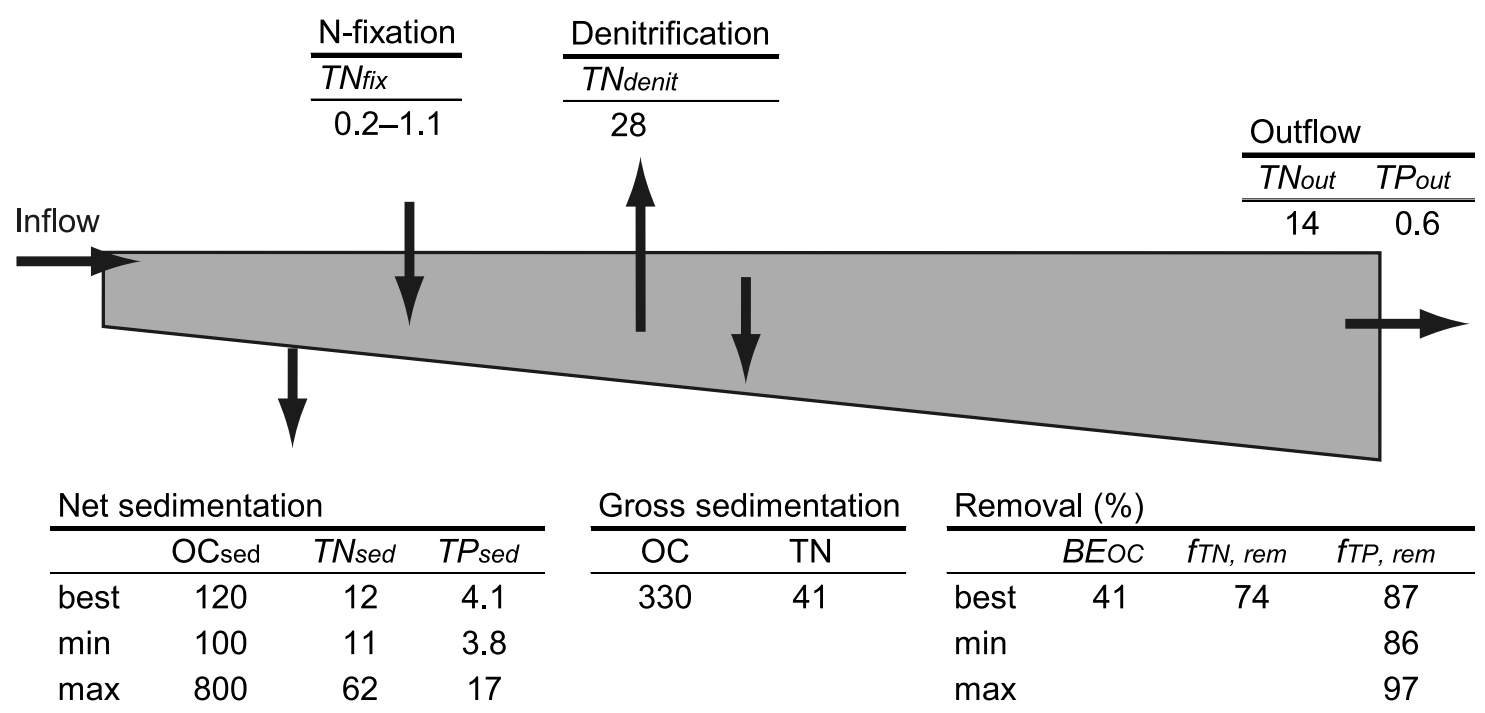

Figure 7. Schematic of input, internal and output loads (in $10^{3} \mathrm{t} \mathrm{yr}^{-1}$ ) used in OC, TN, and TP budget calculations, as well as resulting OC burial efficiency, and TP and TN removal rates (\%). Numbers are best estimates, and, if available lower and upper bonds.

the net $\mathrm{OC}$ accumulation rate divided by the gross $\mathrm{OC}$ accumulation rate [Sobek et al., 2009], is $41 \%$. This value compares well with a calculated $B E$ of $45 \%$ estimated from the relationship

$$
B E=32.1+27.9 \cdot \log \left(\text { Sedimentation rate } \cdot \mathrm{mm}^{-1} \cdot \mathrm{yr}\right)
$$

given by Sobek et al. [2009] using a mean sedimentation rate of $3 \mathrm{~mm} \mathrm{yr}^{-1}$ for Lake Kariba. Both $B E$ values of $41 \%$ and $45 \%$ are specific to lacustrine zones. $B E$ in the deltaic areas would be higher due to greater sedimentation rates and the likelihood that the allochthonous OM, which predominates there, is more refractory than newly produced autochthonous OM. We also calculated the $B E$ using a relationship developed for large natural lakes in relation to their latitude given by Alin and Johnson [2007] and obtained a value of $1.7 \%$. This value substantially underestimates the actual fraction of OC buried, and suggests that large tropical reservoirs such as Lake Kariba may have different characteristics than large natural lakes at low latitudes.

[36] Given that Lake Kariba acts as an efficient trap for allochthonous particles and $\mathrm{OC}$, we hypothesized that it is a net heterotrophic system [Staehr et al., 2010; Tranvik et al., 2009], i.e., that respiration exceeds gross primary production, and as a result water column concentrations of $\mathrm{OC}$ mineralization products, $\mathrm{CO}_{2}$ and $\mathrm{CH}_{4}$, accumulate beyond saturated levels [Sobek et al., 2005]. Net heterotrophic systems are net sources of $\mathrm{CO}_{2}$ (and potentially $\mathrm{CH}_{4}$ ) to the atmosphere [Cole et al., 1994]. Other studies have observed in particular that tropical lakes [Marotta et al., 2009] and reservoirs [Abril et al., 2005] emit substantial amounts of these greenhouse gases. Water column measurements in Lake Kariba from 2007 to 2009 revealed that $\mathrm{CO}_{2}$ was indeed oversaturated by 350 to $1100 \%$, indicating that Lake Kariba is clearly net heterotrophic. Similarly, all observed $\mathrm{CH}_{4}$ concentrations exceeded saturation by $>500 \%$ (T. S. DelSontro et al., Spatial heterogeneity of intense methane ebullition in a large tropical reservoir, submitted to Environmental Science and Technology, 2011).

\subsection{Nitrogen Cycling and Sedimentation}

[37] The creation of Lake Kariba also impacted the downstream transport of fixed $\mathrm{N}$, as evidenced by the accumulation of $\mathrm{N}$ in sediments. To quantify $\mathrm{TN}$ removal and changes in $\mathrm{N}$ cycling, we applied a steady state box model for Lake Kariba that balanced TN sources and sinks:

$$
T N_{\text {in }}+T N_{\text {fix }}=T N_{\text {out }}+T N_{\text {denit }}+T N_{\text {sed }}
$$

where inputs are given by the sum of riverine loads $\left(T N_{i n}\right)$ and $\mathrm{N}$ fixation $\left(T N_{f i x}\right)$, and losses by outflow $\left(T N_{o u t}\right)$, denitrification $\left(T N_{\text {denit }}\right)$, and net $\mathrm{N}$ accumulation in the sediment $\left(T N_{\text {sed }}\right)$. The best estimate of $T N_{\text {sed }}$ was $12 \times 10^{3} \mathrm{t} \mathrm{N} \mathrm{yr}^{-1}$, with lower and upper bounds of 11 to $62 \times 10^{3} \mathrm{t} \mathrm{N} \mathrm{yr}^{-1}$ (Table 4). $T N_{\text {out }}$ was calculated using the mean outflow concentration of $340 \mu \mathrm{g} \mathrm{TN}{ }^{-1}$ and a mean discharge of $42 \mathrm{~km}^{3} \mathrm{yr}^{-1}$ [Beilfuss and Dos Santos, 2001], yielding a value of $14 \times 10^{3} \mathrm{t} \mathrm{N} \mathrm{yr}^{-1}$. Low $\delta^{15} \mathrm{~N}$ and relatively high $\mathrm{C}: \mathrm{N}$ of sediment trap samples (Figure 3 and Table 1) are consistent with $\mathrm{N}$ deficiency [Das et al., 2008; Talbot, 2001]. The low $\delta^{15} \mathrm{~N}$, along with low $\mathrm{N}: \mathrm{P}$, may also suggest that $\mathrm{N}$ fixation is taking place (Figure S1, available as auxiliary material). This is in accordance with evidence of annual cyanobacteria blooms during the rainy season [Ramberg, 1987] and measured $\mathrm{N}$ fixation rates ranging from 0.04 to $0.2 \mathrm{~g} \mathrm{~N} \mathrm{~m}^{-2} \mathrm{yr}^{-1}$ [Moyo, 1997]. However, extrapolating these rates to the entire lake area results in an estimate for $T N_{f i x}$ of 0.2 to $1.1 \times$ $10^{3} \mathrm{t} \mathrm{N} \mathrm{yr}^{-1}$, which is tenfold to fiftyfold lower than $T N_{\text {sed }}$ (Table 4). Thus, $\mathrm{N}$ fixation appears to be a relatively unimportant source of fixed $\mathrm{N}$ to the system. The denitrification loss for Basin IV was calculated as the difference between the mean gross TN sedimentation rate $(=7.7 \pm 2.5 \mathrm{~g} \mathrm{~N}$ $\mathrm{m}^{-2} \mathrm{yr}^{-1}$, based on sediment trap data) and the mean net TN accumulation rate at B41, B51, B55, B61, and B99 $(=2.5 \pm$ $\left.1.0 \mathrm{~g} \mathrm{~N} \mathrm{~m}^{-2} \mathrm{yr}^{-1}\right)$. Extrapolated to the entire lake surface, this difference of $5.2 \pm 3.6 \mathrm{~g} \mathrm{~N} \mathrm{~m}^{-2} \mathrm{yr}^{-1}$ results in a denitrification estimate $T N_{\text {denit }}$ of $(28 \pm 19) \times 10^{3} \mathrm{t} \mathrm{N} \mathrm{yr}^{-1}$, which compares well with the difference between gross TN sedi- 
mentation and $T N_{\text {sed }}\left(=29 \times 10^{3} \mathrm{t} \mathrm{N} \mathrm{yr}^{-1}\right.$; Table 3). Hence, denitrification appears to be an important TN sink $(\sim 50 \%$ of all TN losses).

[38] Based on equation (4), we calculated the fraction of $\mathrm{TN}$ inputs that are removed within the reservoir:

$$
f_{T N, \text { rem }} \approx \frac{T N_{\text {sed }}+T N_{\text {denit }}}{T N_{\text {in }}+T N_{\text {fix }}} \approx \frac{T N_{\text {sed }}+T N_{\text {denit }}}{T N_{\text {out }}+T N_{\text {denit }}+T N_{\text {sed }}}
$$

Using best estimates for $T N_{\text {sed }}\left(12 \times 10^{3} \mathrm{t} \mathrm{N} \mathrm{yr}^{-1}\right), T N_{\text {out }}$ $\left(\sim 14 \times 10^{3} \mathrm{t} \mathrm{N} \mathrm{yr}^{-1}\right)$, and $T N_{\text {denit }}\left(\sim 29 \times 10^{3} \mathrm{t} \mathrm{N} \mathrm{yr}^{-1}\right)$, we obtained $f_{T N \text { rem }}=74 \%$. Two thirds of this $\mathrm{N}$ removal originated from denitrification and one third from net sediment accumulation. This $74 \%$ removal efficiency places Lake Kariba at the upper end of observed values for tropical reservoirs (0.04 to $70 \%$ [Harrison et al., 2009]). On the other hand, $T N_{\text {sed }}+T N_{\text {denit }}$ translates to an areal rate of $7.7 \mathrm{~g} \mathrm{~N} \mathrm{~m}^{-2} \mathrm{yr}^{-1}$, which is approximately threefold smaller than the global mean reservoir $\mathrm{N}$ removal rate [Harrison et al., 2009], and thus overall $\mathrm{N}$ loading to and removal by Lake Kariba are relatively low. There is substantial uncertainty associated with this $\mathrm{N}$ removal estimate due to the lack of direct measurements of $\mathrm{N}$ fixation and denitrification, and the uncertainty related to deltaic sedimentation. Nonetheless, our results suggest an efficient $\mathrm{N}$ removal in Lake Kariba, and thus a substantial decrease in the delivery of $\mathrm{N}$ to downstream systems.

\subsection{Phosphorus Cycling and Sedimentation}

[39] The cycling and removal of TP in Lake Kariba were explored following a similar approach as described for TN by adjusting equations (4) and (5). Using a mean outflow concentration of $14 \mu \mathrm{g}$ TP $1^{-1}$ and a mean discharge of $42 \mathrm{~km}^{3} \mathrm{yr}^{-1}$ [Beilfuss and Dos Santos, 2001], TP out $=0.6 \times$ $10^{3} \mathrm{t} \mathrm{P} \mathrm{yr}^{-1}$. Based on the estimated TP accumulation rates $\left(T P_{\text {sed }}=4.1 \times 10^{3} \mathrm{t} \mathrm{P} \mathrm{yr}^{-1}\right.$, range $=3.8$ to $17 \times 10^{3} \mathrm{t} \mathrm{P} \mathrm{yr}^{-1}$, Table 4$), f_{T P, \text { rem }}=87 \%$ (range $=86$ to $97 \%$ ). Global scale models predict that only $13 \%$ of riverine transported particulate $\mathrm{P}$ is trapped in regulated basins worldwide; the prediction for Africa is $18 \%$ [Beusen et al., 2005]. The relatively high $\mathrm{P}$ removal potential found in our study is however reasonable given the long hydraulic residence time ( $\sim 3$ years) and high sediment removal potential of Lake Kariba [Vörösmarty et al., 2003; Beusen et al., 2005]. Magadza [1992] also predicted a high P removal capacity of Lake Kariba, although the magnitude of that study's P loads were considerably lower than our combined sinks (factor of 4), perhaps suggesting a substantial underestimate.

\section{Conclusions}

[40] Our observations illustrate that Lake Kariba has substantially altered the downstream transport of particles, carbon (C) and nutrients in the Zambezi (Figure 7). Sediment accumulation rates and organic matter signatures were found to vary strongly within and between sediment sampling sites. These variations are attributed to annual flood deposits, which delivered large amounts of allochthonous matter to the lake. Thicknesses of these flood deposits vary interannually depending on the discharge of the tributaries. The estimated annual sediment retention was $\sim 4 \times 10^{6} \mathrm{t} \mathrm{yr}^{-1}$, and the net accumulation rates of organic $\mathrm{C}$, nitrogen $(\mathrm{N})$ and phosphorus $(\mathrm{P})$ are on the order of $\sim 100 \times 10^{3} \mathrm{t} \mathrm{C} \mathrm{yr}^{-1}$, $\sim 11 \times 10^{3} \mathrm{t} \mathrm{N} \mathrm{yr}^{-1}$ and $\sim 4.1 \times 10^{3} \mathrm{t} \mathrm{P} \mathrm{yr}^{-1}$, respectively. This $\mathrm{P}$ accumulation rate in Kariba's sediments corresponds to $87 \%$ removal efficiency of total $\mathrm{P}$ inputs. The $\mathrm{N}$ removal efficiency was found to be somewhat lower (74\%), with important contributions from both denitrification and sediment accumulation. The removal of particles in the reservoir in general undoubtedly contributes to net bank and channel erosion downstream of the dam. In addition, the decreases of riverine $\mathrm{C}, \mathrm{N}$ and $\mathrm{P}$ transport, downstream ecosystem may have adverse biogeochemical impacts, especially considering that Lake Kariba attenuates the flow from $\sim 50 \%$ of the Zambezi Basin. For example, sensitive ecosystems, such as floodplains, may experience ecological changes due to altered nutrient availability. Similarly, flood-recession agriculture and coastal fisheries may be jeopardized due to nutrient deficiencies. These impacts are of special concern in developing countries owing to the generally $\mathrm{OC}$ and nutrient depleted soils and the limited availability of fertilizers.

[41] In a broader context, the OC accumulation rate of $\sim 20 \mathrm{~g} \mathrm{C} \mathrm{m}^{-2} \mathrm{yr}^{-1}$ is lower than the global mean for reservoirs. Nevertheless, the retained mass of $\mathrm{OC}$ in such a large lake contributes substantially to the anthropogenically induced shift in $\mathrm{C}$ burial on land instead of in the oceans.

[42] Acknowledgments. The project was funded as part of the ADAPT project of the Competence Center Environment and Sustainability (CCES) and obtained additional support from Eawag. We thank the staff of the Zambezi River Authority Tedious Gumi, Clement Mukosa, Pherry Mwiinga, Mavis Nawa, and Evis Siamachoka at Lusaka and Kariba Town for logistical support, and the Eawag staff Christian Dinkel, Daniel Ineichen, Ruth Stierli, Leticia Stojkovski, and Alois Zwyssig for field and laboratory assistance. An earlier version of the manuscript could be improved significantly thanks to the helpful comments by two anonymous reviewers.

\section{References}

Abril, G., F. Guérin, S. Richard, R. Delmas, C. Galy Lacaux, P. Gosse, A. Tremblay, L. Varfalvy, M. A. Dos Santos, and B. Matvienko (2005), Carbon dioxide and methane emissions and the carbon budget of a 10-year old tropical reservoir (Petit Saut, French Guiana), Global Biogeochem. Cycles, 19, GB4007, doi:10.1029/2005GB002457.

Alin, S. R., and T. C. Johnson (2007), Carbon cycling in large lakes of the world: A synthesis of production, burial, and lake-atmosphere exchange estimates, Global Biogeochem. Cycles, 21, GB3002, doi:10.1029/ 2006GB002881.

Attwell, R. I. G. (1970), Some effects of Lake Kariba on the ecology of a floodplain of the Mid-Zambezi Valley of Rhodesia, Biol. Conserv., 2, 189-196, doi:10.1016/0006-3207(70)90106-0.

Bartle, A. (2002), Hydropower potential and development activities, Energy Policy, 30, 1231-1239, doi:10.1016/S0301-4215(02)00084-8.

Battin, T. J., S. Luyssaert, L. A. Kaplan, A. K. Aufdenkampe, A. Richter, and L. J. Tranvik (2009), The boundless carbon cycle, Nat. Geosci., 2, 598-600, doi:10.1038/ngeo618.

Beilfuss, R. D., and B. R. Davies (1999), Prescribed flooding and wetland rehabilitation in the Zambezi Delta, Mozambique, in An International Perspective on Wetland Rehabilitation, edited by W. Streever, pp. 143158, Kluwer Acad., Dordrecht, Netherlands.

Beilfuss, R. D., and D. Dos Santos (2001), Patterns of hydrological change in the Zambezi Delta, Mozambique, Working Pap. 2, Zambezi Basin Crane and Wetland Conserv. Program, Baraboo, Wis.

Beusen, A. H. W., A. L. M. Dekkers, A. F. Bouwman, W. Ludwig, and J. Harrison (2005), Estimation of global river transport of sediments and associated particulate C, N, and P, Global Biogeochem. Cycles, 19, GB4S05, doi:10.1029/2005GB002453.

Bolton, P. (1984), Sediment deposition in major reservoirs in the Zambezi Basin, in Challenges in African Hydrology and Water Resources, IAHS Publ., 144, 559-567.

Bosch, N. S. (2008), The influence of impoundments on riverine nutrient transport: An evaluation using the Soil and Water Assessment Tool, J. Hydrol., 355, 131-147, doi:10.1016/j.jhydrol.2008.03.012. 
Bosch, N. S., and J. D. Allan (2008), The influence of impoundments on nutrient budgets in two catchments of southeastern Michigan, Biogeochemistry, 87, 325-338, doi:10.1007/s10533-008-9187-6.

Coche, A. G. (1968), Description of physico-chemical aspects of Lake Kariba, an impoundment, in Zambia-Rhodesia, Fish. Res. Bull. Zambia, $5,200-267$.

Coche, A. G. (1974), Limnological study of a tropical reservoir, in Lake Kariba: A Man-Made Tropical Ecosystem in Central Africa, edited by E. K. Balon and A. G. Coche, pp. 1-247, Dr. W. Junk, The Hague, Netherlands.

Cole, J. J., N. F. Caraco, G. W. Kling, and T. K. Kratz (1994), Carbon dioxide supersaturation in the surface waters of lakes, Science, 265, 1568-1570, doi:10.1126/science.265.5178.1568.

Cole, J. J., Y. T. Prairie, N. F. Caraco, W. H. McDowell, L. J. Tranvik, R. G. Striegl, C. M. Duarte, P. Kortelainen, J. A. Downing, and J. J. Middelburg (2007), Plumbing the global carbon cycle: Integrating inland waters into the terrestrial carbon budget, Ecosystems, 10, 172-185, doi:10.1007/s10021-006-9013-8.

Das, S. K., J. Routh, A. N. Roychoudhury, and J. V. Klump (2008), Elemental $(\mathrm{C}, \mathrm{N}, \mathrm{H}$ and $\mathrm{P})$ and stable isotope $\left(\delta^{15} \mathrm{~N}\right.$ and $\left.\delta^{13} \mathrm{C}\right)$ signatures in sediments from Zeekoevlei, South Africa: A record of human intervention in the lake, J. Paleolimnol., 39, 349-360, doi:10.1007/s10933-0079110-5.

Dean, W. E., and E. Gorham (1998), Magnitude and significance of carbon burial in lakes, reservoirs, and peatlands, Geology, 26, 535-538, doi:10.1130/0091-7613(1998)026<0535:MASOCB $>2.3 . C O ; 2$.

de Junet, A., G. Abril, F. Guérin, I. Billy, and R. de Wit (2009), A multitracers analysis of sources and transfers of particulate organic matter in a tropical reservoir (Petit Saut, French Guiana), River Res. Appl., 25, 253 271, doi:10.1002/rra.1152.

DelSontro, T., D. F. McGinnis, S. Sobek, I. Ostrovsky, and B. Wehrl (2010), Extreme methane emissions from a Swiss hydropower reservoir: Contribution from bubbling sediments, Environ. Sci. Technol., 44, 2419 2425, doi:10.1021/es9031369.

DEW (2002), German Standard Methods for the Examination of Water, Wastewater, and Sludge, Wiley VCH, Weinheim, Germany.

Downing, J. A., Y. T. Prairie, J. J. Cole, C. M. Duarte, L. J. Tranvik, R. G. Striegl, W. H. McDowell, P. Kortelainen, N. F. Caraco, and J. M. Melack (2006), The global abundance and size distribution of lakes, ponds, and impoundments, Limnol. Oceanogr., 51, 2388-2397, doi:10.4319 lo.2006.51.5.2388.

Downing, J. A., J. J. Cole, J. J. Middelburg, R. G. Striegl, C. M. Duarte, P. Kortelainen, Y. T. Prairie, and K. A. Laube (2008), Sediment organic carbon burial in agriculturally eutrophic impoundments over the last century, Global Biogeochem. Cycles, 22, GB1018, doi:10.1029/ 2006GB002854.

Friedl, G., and A. Wüest (2002), Disrupting biogeochemical cycles: Consequences of damming, Aquat. Sci., 64, 55-65, doi:10.1007/s00027-0028054-0.

Fry, B. (2006), Stable Isotope Ecology, doi:10.1007/0-387-33745-8, Springer, New York.

Guy, P. R. (1981), River bank erosion in the mid-Zambezi valley, downstream of Lake Kariba, Biol. Conserv., 19, 199-212, doi:10.1016/ 0006-3207(81)90035-5.

Haregeweyn, N., J. Poesen, J. Deckers, J. Nyssen, M. Haile, G. Govers, G. Verstraeten, and J. Moeyersons (2008), Sediment-bound nutrien export from micro-dam catchments in Northern Ethiopia, Land Degrad. Dev., 19, 136-152, doi:10.1002/ldr.830.

Harrison, J. A., R. J. Maranger, R. B. Alexander, A. E. Giblin, P. A Jacinthe, E. Mayorga, S. P. Seitzinger, D. J. Sobota, and W. M. Wollheim (2009), The regional and global significance of nitrogen removal in lakes and reservoirs, Biogeochemistry, 93, 143-157, doi:10.1007/s10533-0089272-x.

Hydropower and Dams (2001), World Atlas and Industry Guide, AquaMedia Int., Wallington, U. K

Karenge, L., and J. Kolding (1995), On the relationship between hydrology and fisheries in man-made Lake Kariba, Central Africa, Fish. Res., 22 , 205-226, doi:10.1016/0165-7836(94)00325-Q

Lamb, A. L., G. P. Wilson, and M. J. Leng (2006), A review of coastal palaeoclimate and relative sea-level reconstructions using delta $\mathrm{C}-13$ and $\mathrm{C} / \mathrm{N}$ ratios in organic material, Earth Sci. Rev., 75, 29-57, doi:10.1016/j.earscirev.2005.10.003.

Latrubesse, E. M., J. C. Stevaux, and R. Sinha (2005), Tropical rivers, Geomorphology, 70, 187-206, doi:10.1016/j.geomorph.2005.02.005.

Magadza, C. H. D. (1992), Synopsis of scientific results of the SAREC sponsored project on the ecology of Lake Kariba, Hydrobiologia, 232, 73-77, doi:10.1007/BF00014614.
Magadza, C. H. D. (2006), Kariba reservoir: Experience and lessons learned, Lakes Reservoirs Res. Manage., 11, 271-286, doi:10.1111/ j.1440-1770.2006.00308.x.

Marotta, H., C. M. Duarte, S. Sobek, and A. Enrich-Prast (2009), Large $\mathrm{CO}_{2}$ disequilibria in tropical lakes, Global Biogeochem. Cycles, 23, GB4022, doi:10.1029/2008GB003434.

Marshall, B. E. (1979), Fish populations and the fisheries potential of Lake Kariba, S. Afr. J. Sci., 75, 485-488.

Marshall, B. E. (1988), Seasonal and annual variations in the abundance of pelagic sardines in Lake Kariba, with special reference to the effects of drought, Arch. Hydrobiol., 112, 399-409.

Matzinger, A., R. Pieters, K. I. Ashley, G. A. Lawrence, and A. Wüest (2007), Effects of impoundment on nutrient availability and productivity in lakes, Limnol. Oceanogr., 52, 2629-2640, doi:10.4319/ lo.2007.52.6.2629.

McCartney, M. (2009), Living with dams: Managing the environmental impacts, Water Policy, 11, 121-139, doi:10.2166/wp.2009.108.

Meyers, P. A., and E. Lallier-Verges (1999), Lacustrine sedimentary organic matter records of Late Quaternary paleoclimates, J. Paleolimnol., 21, 345-372, doi:10.1023/A:1008073732192.

Meyers, P. A., and J. L. Teranes (2002), Sediment organic matter, in Tracking Environmental Change Using Lake Sediments, edited by W. M. Last and J. P. Smol, pp. 239-269, doi:10.1007/0-306-47670-3 9, Kluwer, Dordrecht, Netherlands.

Milliman, J. D., and R. H. Meade (1983), World-wide delivery of river sediment to the oceans, J. Geol., 91, 1-21, doi:10.1086/628741.

Moyo, S. M. (1997), Contribution of nitrogen fixation to the nitrogen budget of Lake Kariba, in Advances in the Ecology of Lake Kariba, edited by J. Moreau, pp. 11-57, Univ. of Zimbabwe, Harare.

Müller, G., and M. Gastner (1971), The "Karbonat Bombe", a simple device for the determination of the carbonate content in sediments, soils and other materials, Neues Jb. Mineral. Monat., 10, 466-469.

Ramberg, L. (1987), Phytoplankton succession in the Sanyati Basin, Lake Kariba, Hydrobiologia, 153, 193-202, doi:10.1007/BF00007206.

Richter, B. D., J. V. Baumgartner, J. Powell, and D. P. Braun (1996), A method for assessing hydrologic alteration within ecosystems, Conserv. Biol., 10, 1163-1174, doi:10.1046/j.1523-1739.1996.10041163.x.

Ronco, P., G. Fasolato, M. Nones, and G. Di Silvio (2009), Morphological effects of damming on lower Zambezi River, Geomorphology, 115, 43-55, doi:10.1016/j.geomorph.2009.09.029.

Rosenberg, D. M., P. McCully, and C. M. Pringle (2000), Global-scale environmental effects of hydrological alterations: Introduction, BioScience, 50, 746-751, doi:10.1641/0006-3568(2000)050[0746:GSEEOH] 2.0.CO;2.

Rowan, D. J., J. Kalff, and J. B. Rasmussen (1992), Estimating the mud deposition boundary depth in lakes from wave theory, Can. J. Fish Aquat. Sci., 49, 2490-2497, doi:10.1139/f92-275.

Scodanibbio, L., and G. Mañez (2005), The World Commission on Dams: A fundamental step towards integrated water resources management and poverty reduction? A pilot case in the Lower Zambezi, Mozambique, Phys. Chem. Earth, 30, 976-983, doi:10.1016/j.pce.2005.08.045.

Shela, O. N. (2000), Management of shared river basins: The case of the Zambezi River, Water Policy, 2, 65-81, doi:10.1016/S1366-7017(99) 00022-7.

Shotbolt, L. A., A. D. Thomas, and S. M. Hutchinson (2005), The use of reservoir sediments as environmental archives of catchment inputs and atmospheric pollution, Prog. Phys. Geogr., 29, 337-361, doi:10.1191/ 0309133305pp452ra.

Sobek, S., L. J. Tranvik, and J. J. Cole (2005), Temperature independence of carbon dioxide supersaturation in global lakes, Global Biogeochem. Cycles, 19, GB2003, doi:10.1029/2004GB002264.

Sobek, S., E. Durisch-Kaiser, R. Zurbrügg, N. Wongfun, M. Wessels, N. Pasche, and B. Wehrli (2009), Organic carbon burial efficiency in lake sediments controlled by oxygen exposure time and sediment source, Limnol. Oceanogr., 54, 2243-2254, doi:10.4319/lo.2009.54.6.2243.

Soils Incorporated (Pty) Ltd and Chalo Environmental and Sustainable Development Consultants (2000), Kariba Dam case study, prepared as an input to the World Commission on Dams, Cape Town.

Staehr, P. A., K. Sand-Jensen, A. L. Raun, B. Nilsson, and J. Kidmosec (2010), Drivers of metabolism and net heterotrophy in contrasting lakes, Limnol. Oceanogr., 55, 817-830, doi:10.4319/10.2009.55.2.0817.

Stallard, R. F. (1998), Terrestrial sedimentation and the carbon cycle: Coupling weathering and erosion to carbon burial, Global Biogeochem Cycles, 12, 231-257, doi:10.1029/98GB00741.

Talbot, M. R. (2001), Nitrogen isotopes in palaeolimnology, in Tracking Environmental Change Using Lake Sediments, edited by W. M. Last and J. P. Smol, pp. 401-439, Kluwer, Dordrecht, Netherlands. 
Teodoru, C., and B. Wehrli (2005), Retention of sediments and nutrients in the Iron Gate I Reservoir on the Danube River, Biogeochemistry, 76, 539-565, doi:10.1007/s10533-005-0230-6.

Tranvik, L. J., J. A. Downing, J. B. Cotner, S. A. Loiselle, R. G. Striegl, T. J. Ballatore, P. Dillon, K. Finlay, K. Fortino, and L. B. Knoll (2009), Lakes and reservoirs as regulators of carbon cycling and climate, Limnol. Oceanogr., 54, 2298-2314, doi:10.4319/lo.2009.54.6 part 2.2298.

Vörösmarty, C. J., and B. Moore (1991), Modeling basin-scale hydrology in support of physical climate and global biogeochemical studies-An example using the Zambezi River, Surv. Geophys., 12, 271-311, doi:10.1007/BF01903422.

Vörösmarty, C. J., M. Meybeck, B. Fekete, K. Sharma, P. Green, and J. P. M. Syvitski (2003), Anthropogenic sediment retention: Major global impact from registered river impoundments, Global Planet. Change, 39, 169-190, doi:10.1016/S0921-8181(03)00023-7.

Walling, D. E. (2006), Human impact on land-ocean sediment transfer by the world's rivers, Geomorphology, 79, 192-216, doi:10.1016/j.geomorph. 2006.06.019.

Wang, L., P. D’Odorico, S. Ringrose, S. Coetzee, and S. A. Macko (2007), Biogeochemistry of Kalahari sands, J. Arid Environ., 71, 259-279, doi:10.1016/j.jaridenv.2007.03.016.
Waterson, E. J., and E. A. Canuel (2008), Sources of sedimentary organic matter in the Mississippi River and adjacent Gulf of Mexico as revealed by lipid biomarker and $\delta^{13} \mathrm{C}_{\mathrm{TOC}}$ analyses, Org. Geochem., 39, 422-439, doi:10.1016/j.orggeochem.2008.01.011.

World Commission on Dams (2000), Dams and development-A new framework for decision-making, report, Earthscan, London.

Yamamuro, M. (2000), Chemical tracers of sediment organic matter origins in two coastal lagoons, J. Mar. Syst., 26, 127-134, doi:10.1016/S09247963(00)00049-X.

Zambezi River Authority (2010), Water resources year-books: Year 1958 year 2010, Lusaka.

F. S. Anselmetti, M. J. Kunz, D. B. Senn, S. Thüring, A. Vollenweider, B. Wehrli, and A. Wüest, Surface Waters-Research and Management, Eawag: Swiss Federal Institute of Aquatic Science and Technology, Seestrasse 79, CH-6047 Kastanienbaum, Switzerland. (manuel.kunz@ eawag.ch) 